\title{
UTILIZATION FROM NEW NUTRITIONAL RESOURCES IN RUMENANT FEEDING: \\ 1- EFFECT OF USING DRIED DISTILLERS GRAINS WITH SOLUBLES(DDGS) IN RATIONS FOR FATTENING FRIESIAN CALVES
}

Etman, K. E. I. ; A. M. M. Zeid and T.I. El-Monayer

Animal Prod. Res. Inst., Agric. Res. Center, Ministry of Agric., Egypt.

\begin{abstract}
Forty-five male Friesian calves averaging $309.86 \mathrm{~kg}$ live body weight (L.B.W.), were divided into three similar groups (15 in each) and used in feeding trial which lasted 172 days. Animals were assigned to receive $2 \%$ of L.B.W. concentrate feed mixture which containing dried distiller grains with solubles (DDGS) at the rate of $0 \%, 10 \%$ and $20 \%$ in rations $A, B$ and $\mathrm{C}$, respectively. All animals offered rice straw at the rate of $1.0 \%$ of L.B.W., plus $2 \mathrm{~kg}$ berseem hay/day. In addition, three digestibility trials ( 3 calves in each) were conducted to determine the digestibility coefficients of all nutrients and feeding values of experimental rations.

The results obtained showed significantly $(P<0.05)$ higher digestibility coefficients and nutritive value of ration C (containing $20 \%$ DDGS) than the control ration (ration $\mathrm{A}$ ).

Average daily gains were $0.898,0.955$ and $1.110 \mathrm{~kg}$ for animals fed rations $A, B$ and $C$, respectively. Animals given ration $C$ grew significantly $(p<0.05)$ higher than those given ration $A$ or $B$. Significant $(P<0.05)$ improvements were recorded for animals fed ration $\mathrm{C}$ with respect to feed conversion efficiency expressed as $\mathrm{kg}$, DM, TDN, SE or DCP/kg gain. Results of ruminal measurements of animals fed rations $\mathrm{B}$ and $\mathrm{C}$ containing $10 \%$ and $20 \%$ DDGS showed high $\mathrm{pH}, \mathrm{NH}_{3}-\mathrm{N}$ and VFA's concentrations. At the same time, serum blood parameters (Total protein, albumin and globulin) showed similar trend. Moreover, animals fed rations containing both $10 \%$ and $20 \%$ DDGS grew faster and had lower cost of feeding with better economical efficiencies, than the control group.
\end{abstract}

\section{INTRODUCTION}

There are limited protein and energy sources for use in ruminant feeds in Egypt. Yellow corn is the main source of energy and is an essential component in cattle feeding. However, the price of yellow corn has increased greatly due to the expansion in its use in the ethanol production as a fuel. Dried distillers grains with solubles (DDGS) is a coproduct of the ethanol industry. This product is high in both energy (85\%TDN) and protein(27\%). Additionally, it is a palatable product and has higher value of available phosphors compared to other protein sources. It also reduces feed cost, improves feed conversion efficiency, fiber digestion in rumen, good source of ruminally undegraded protein and less starch with highly digestible fiber and fats (Harold Harpster, 2007).

This product have been used in many trials as source of energy or protein in ration formulations of dairy animals, beef steers, heifers, sheep, 
poultry and swine (May et al., 2009, Leupp et al., 2009, Widmers, et al., 2008 and Reed et al., 2006).

This study aimed to include DDGS as a feed ingredient at the rate of $10 \%$ and $20 \%$ in place of yellow corn and soyabean meal in rations for fattening Friesian calves. Moreover, digestibility coefficients, feeding values, animal performance, feed conversion and economical efficiencies were studied.

\section{MATERIALS AND METHODS}

Forty-five male Friesian calves averaging $309.86 \mathrm{~kg}$ live body weight (L.B.W.) were used in the feeding trial, during 2009 at Dina El-Maadawy private farm located in the desert road. The trial aimed to evaluate DDGS as a feed ingredient and as a source of protein and energy in fattening Friesian calves.

Animals were randomly chosen and divided into three similar groups according to live body weight and age (15 in each). The three animal groups were fed experimental rations as follows: A) Concentrate feed mixture without DDGS; B) concentrate feed mixture with 10\% DDGS and C) concentrate feed mixture with 20\% DDGS. Dried distillers grains with solubles (DDGS) is a by-product of ethanol production from yellow corn . All animal groups were fed concentrate feed mixture at the rate of $2 \%$ L.B.W. along with $1 \%$ rice straw, in addition to $2 \mathrm{~kg}$ berseem hay/head/day. Weekly body weights and feed intakes were recorded during feeding trials which lasted 172 days. The feed allowances were adjusted every two weeks according to body weight changes using NRC (1989) as reference.

The concentrate feed mixtures were offered to animals twice daily at 8:00 a.m. and 4:00 p.m. followed by berseem hay, while rice straw and water were available during the whole day.

On the other hand, digestibility trial using nine calves in three groups (3 in each) was conducted to determine and evaluate the previous experimental rations. The digestibility trial lasted three weeks, the first two weeks were used as preliminary period along with one week as collection period.

Chemical composition of all ingredients and feces were carried out according to A.O.A.C. (1995).

Blood samples were withdrawn from the jugular vein of calves in each group during the digestibility trial ( $3 \mathrm{hrs}$ post feeding). Serum was separated from blood and kept it in frozen at $-20^{\circ} \mathrm{C}$ for chemical analysis to determine total protein (Cornell et al., 1949), albumin (Doumas et al., 1971), Creatinine (Young, 1990), while globulin concentration was determined by difference between total protein and albumin concentration. On the other hand, rumen liquor samples were taken from three calves in each group before morning feeding and at $3 \mathrm{hrs}$ and $6 \mathrm{hrs}$ post feeding. Each sample was divided into two parts, the $1^{\text {st }}$ for determine the $\mathrm{pH}$ value and the $2^{\text {nd }}$ part was preserved to determine the ammonia- $\mathrm{N}$ concentration (Warner, 1964). 
Data were statistically analyzed by using GLM Programs of the Statistical Analysis System [ SAS ] (SAS, 1996).

The differences among means were tested using Duncan Multiple Range Test (Duncan, 1955).

\section{RESULTS AND DISCUSSION}

Chemical composition of the feed ingredients and the concentrate feed mixture as well as the analysis of rice straw and berseem hay are shown in Table (1).

Table (1): Ingredients of concentrate feed mixtures of three experimental rations

\begin{tabular}{|l|c|c|c|c|c|}
\hline \multirow{2}{*}{ Items } & \multicolumn{6}{|c|}{ Experimental rations } & \multirow{2}{*}{ Rice straw } & \multirow{2}{*}{ Berseem hay } \\
\cline { 2 - 6 } & A & B & C & & \\
\hline Ingredients (\%): & & & & & \\
\hline Yellow corn & 52 & 47 & 42 & & \\
\hline Wheat bran & 18 & 18 & 18 & & \\
\hline Soya bean meal (44\%) & 10 & 5 & - & & \\
\hline Brewers pulp & 12 & 12 & 12 & & \\
\hline Undecorticated cotton seed cake & 5 & 5 & 5 & & \\
\hline Dried distiller grains (DDGS) & - & 10 & 20 & & \\
\hline Line stone & 2 & 2 & 2 & & \\
\hline Salt & 1 & 1 & 1 & & \\
\hline Chemical composition of concentrate feed mixture, rice straw and berseem hay: \\
\hline DM & 92.20 & 90.14 & 90.60 & 92.10 & 91.16 \\
\hline OM & 96.71 & 96.69 & 96.68 & 85.76 & 89.62 \\
\hline CP & 14.50 & 14.56 & 14.62 & 4.86 & 12.44 \\
\hline EE & .3 .10 & 3.60 & 4.11 & 1.76 & 2.86 \\
\hline CF & 7.72 & 8.08 & 8.44 & 39.94 & 26.65 \\
\hline NFE & 71.39 & 70.45 & 69.51 & 39.20 & 47.67 \\
\hline Ash & 3.29 & 3.31 & 3.32 & 14.24 & 10.38 \\
\hline
\end{tabular}

*DDGS contains: $29,61 \%$ CP, $8.79 \%$ Starch, $36.43 \%$ NDF and $18.38 \%$ ADF(Reed et al., 2006)

It could be noticed that the nutrients contents for the concentrate feed mixtures were almost equal especially in organic matter( $O M)$, crude protein( CP), nitrogen free extractives( NFE) and ash contents. There was a slight increase in the $\mathrm{CP}$ and ether extract( EE) contents of concentrate feed of rations $B$ and $C$ due to the higher protein and energy content of DDGS which is included in the rations $B$ and $C$. The results of the chemical analysis of rice straw and berseem hay were similar with those reported by (Etman et al., 2001).

The calculated compositions of experimental rations are presented in Table (2), which shows that the different rations were almost similar in nutrient contents.

Moreover, rations $\mathrm{B}$ and $\mathrm{C}$ containing DDGS at the rate of $10 \%$ and $20 \%$, respectively, tended to have slightly higher EE and lower CF contents compared with the control ration. The digestibility coefficients of all nutrients for tested rations ( $B$ and $C$ rations) were significantly $(P<0.05)$ 
higher than those recorded for ration $A$ (control ration), except for $E E$ and NFE digestibilities, while differences between ration $B$ and both of ration $A$ and ration $C$ with respect to $C F$ digestibility was not significant (Table, 2).

Table (2): Average daily feed intake, calculate composition, digestibility coefficient and nutritive value of different experimental rations

\begin{tabular}{|l|c|c|c|}
\hline \multirow{2}{*}{ Items } & \multicolumn{3}{c|}{ Experimental rations } \\
\cline { 2 - 4 } & A & B & C \\
\hline Average daily feed intake (kg DM/head): & & & \\
\hline Concentrate feed mixture & 6.825 & 6.860 & 7.023 \\
\hline Rice straw & 1.950 & 1.960 & 2.015 \\
\hline Berseem hay & 0.975 & 0.980 & 1.008 \\
\hline Total DM intake & 9.750 & 9.800 & 10.075 \\
\hline Calculate composition of experimental rations: & & & \\
\hline DM & 90.08 & 90.63 & 92.96 \\
\hline OM & 93.79 & 93.80 & 93.81 \\
\hline CP & 12.36 & 12.40 & 12.44 \\
\hline EE & 2.81 & 3.16 & 3.52 \\
\hline CF & 16.57 & 16.32 & 16.06 \\
\hline NFE & 62.05 & 61.92 & 61.79 \\
\hline Ash & 6.21 & 6.20 & 6.19 \\
\hline Digestibility coefficients, (\%): & & & \\
\hline DM & $75.45^{\mathrm{b}}$ & $80.16^{\mathrm{a}}$ & $80.84^{\mathrm{a}}$ \\
\hline OM & $79.81^{\mathrm{b}}$ & $82.11^{\mathrm{a}}$ & $83.53^{\mathrm{a}}$ \\
\hline CP & $85.42^{\mathrm{b}}$ & $90.00^{\mathrm{a}}$ & $90.28^{\mathrm{a}}$ \\
\hline EE & $90.61^{\mathrm{a}}$ & $90.24^{\mathrm{a}}$ & $90.16^{\mathrm{a}}$ \\
\hline CF & $75.48^{\mathrm{b}}$ & $79.16^{\mathrm{ab}}$ & $82.78^{\mathrm{a}}$ \\
\hline NFE & $80.35^{\mathrm{a}}$ & $80.32^{\mathrm{a}}$ & $80.18^{\mathrm{a}}$ \\
\hline Nutritive value, (\%): & & & \\
\hline TDN & $75.67^{\mathrm{b}}$ & $80.38^{\mathrm{a}}$ & $81.20^{\mathrm{a}}$ \\
\hline SE & $64.73^{\mathrm{b}}$ & $69.81^{\mathrm{a}}$ & $70.92^{\mathrm{a}}$ \\
\hline DCP & $10.55^{\mathrm{b}}$ & $11.16^{\mathrm{a}}$ & $11.23^{\mathrm{a}}$ \\
\hline
\end{tabular}

$a$ and $b$ : Means in the same row with different superscripts are differ $(P<0.05)$.

Generally, using DDGS as a partial replacement of yellow corn and soyabean meal in rations for fattening Friesian calves appeared to have higher digestibility coefficients for most nutrients. Also, the nutritive values of the rations containing DDGS (B and $C$ rations) in terms of TDN, SE and DCP had significantly $(P<0.05)$ higher values, being $80.38,69.81$ and $11.16 \%$,respectively for ration $\mathrm{B} ; 81.20,70.92$ and $11.23 \%$ for ration $\mathrm{C}$. Higher digestibility of most nutrients for the rations containing DDGS (rations $\mathrm{B}$ and $\mathrm{C}$ ) might be attributed to higher digestibility and availability of nutrient contents of DDG as reported by DeHaan et al. (1982) and Kleinschmit et al. (2006).

\section{Effect of feeding DDGS on growth performance}

Results of growth performance presented in Table (3) showed higher daily live body weight gains for animals fed tested rations $B$ and $C$, which containing DDGS being 0.955 and $1.110 \mathrm{~kg}$, respectively. Adding DDGS as 
a source of energy and protein ingredient to tested rations at the rate of $20 \%$ significantly $(\mathrm{P}<0.05)$ improved daily gain by $23.61 \%$, but using DDGS at the rate of $10 \%$ showed only $6.32 \%$ higher daily gain with the control ration.

Table (3): Average daily gain, feed efficiency and feed cost of animals fed different experimental rations

\begin{tabular}{|l|c|c|c|}
\hline \multirow{2}{*}{ Items } & \multicolumn{3}{c|}{ Experimental rations } \\
\cline { 2 - 4 } & A & B & C \\
\hline No. of animals & 15 & 15 & 15 \\
\hline Experimental periods, day & 172 & 172 & 172 \\
\hline Av. initial L.B.W., $\mathrm{kg}$ & 313.00 & 309.50 & 307.08 \\
\hline Av. final L.B.W., $\mathrm{kg}$ & 467.50 & 473.73 & 498.10 \\
\hline Av. total L.B.W., kg & 154.50 & 164.23 & 191.02 \\
\hline Av. daily L.B.W., kg & $0.898^{\mathrm{b}}$ & $0.955^{\mathrm{ab}}$ & $1.110^{\mathrm{a}}$ \\
\hline Av. daily feed unit intake: & & & \\
\hline $\mathrm{kg}$ DM & 9.750 & 9.800 & 10.075 \\
\hline $\mathrm{kg}$ TDN & 7.378 & 7.877 & 8.181 \\
\hline $\mathrm{kg}$ SE & 6.311 & 6.841 & 7.145 \\
\hline $\mathrm{kg}$ DCP & 1.029 & 1.094 & 1.131 \\
\hline Feed conversion efficiency: & & & \\
\hline $\mathrm{kg}$ DM/kg gain & $10.857^{\mathrm{a}}$ & $10.262^{\mathrm{a}}$ & $9.076^{\mathrm{b}}$ \\
\hline $\mathrm{kg}$ TDN/kg gain & $8.216^{\mathrm{a}}$ & $8.248^{\mathrm{a}}$ & $7.370^{\mathrm{b}}$ \\
\hline $\mathrm{kg}$ SE/kg gain & $7.028^{\mathrm{a}}$ & $7.163^{\mathrm{a}}$ & $6.437^{\mathrm{b}}$ \\
\hline $\mathrm{kg}$ DCP/kg gain & $1.146^{\mathrm{a}}$ & $1.146^{\mathrm{a}}$ & $1.019^{\mathrm{b}}$ \\
\hline Feed cost and economical efficiency, LE: & & & \\
\hline${ }^{\star}$ Cost of feed intake $/ \mathrm{kg}$ gain & 9.779 & 9.484 & 9.399 \\
\hline Price of kg weight gain & 13.470 & 14.325 & 16.650 \\
\hline Feed cost /kg weight gain & 10.889 & 9.931 & 8.468 \\
\hline Economical efficiency & 1.377 & 1.510 & 1.771 \\
\hline Improvement (\%) & - & 9.66 & 28.61 \\
\hline
\end{tabular}

$a$ and $b$ : Means in the same row with different superscripts are differ $(P<0.05)$.

* Based on the assumption that the price of one ton of rice straw was 66 LE; Barseem hay was $600 \mathrm{LE}$; concentrate feed mixture was 1330, 1280 and 1235 LE; with rations $A, B$ and $C$, respectively, while the price of one $\mathrm{kg}$ body weight on selling was $18.00 \mathrm{LE}$.

Higher daily gain of animals fed rations containing DDGS might be attributed to higher protein and energy contents of DDGS along with its higher nutrients digestibility . The results reported by May et al. (2009), Leupp et al. (2009) and Trankle, (2003), support the present results.

Moreover, distiller dried grains (DDGS) is a good source of undegradable protein which is about $50 \%$ of its total protein, which could be absorbed post-ruminally as amino acids and it makes together with microbial protein to support more gains for animals. Also, rations containing DDGS was also useful for the animals owing to its content of fermented effective fiber (34\% NDF) and (13\% fat) on DM basis.

Effect of feeding DDGS on feed conversion efficiency

Data presented in Table (3) showed feed conversion efficiency expressed as amounts of $\mathrm{kg}$ DM, TDN, SE or DCP to get one $\mathrm{kg}$ gain. Results obtained revealed that, animals fed ration C containing 20\% DDGS 
had significantly $(\mathrm{P}<0.05)$ the highest feed conversion efficiency, being 9.076, 7.370, 6.437 and $1.019 \mathrm{~kg} \mathrm{DM}$, TDN, SE and DCP,respectively.The improved feed conversion efficiency for ration C (containing 20\% DDGS) might be attributed to higher final and daily weight gain compared to animals given the others. On the contrary, ration B (containing 10\% DDGS) tended to have lower feed conversion efficiency than ration $C$ with no significant differences (Table 3).

Ham et al. (1994), Kleinschmit et al. (2006) and DeHaan et al. (1982),reported similar results on cattle,sheep and poultry

From these results, it could be noticed that the improvement in feed conversion efficiency was related to feed intake and average daily gains.

\section{Economical efficiency}

Results obtained in Table (3) showed that the lowest feed cost $/ \mathrm{kg}$ weight gain was recorded with ration C (containing 20\% DDGS) followed by ration $\mathrm{B}$ (containing 10\% DDGS), being 8.468 and 9.931 L.E., respectively, while control ration (ration A) was the most expensive (10.889 L.E. feed cost $/ \mathrm{kg}$ weight gain). The economical efficiency (feed cost of $\mathrm{kg}$ gain/cost of feed intake) recorded 1.377, 1.510 and 1.771 for rations $A, B$ and $C$, respectively, showing the best economical efficiency was recorded for ration $\mathrm{C}$ (containing 20\% DDGS) followed by ration $\mathrm{B}$ (containing 10\% DDGS) and was least for ration A (without DDGS). The improvement in economical efficiency was 28.61 and $9.66 \%$ with ration $\mathrm{C}$ and $\mathrm{B}$, respectively. Similar results have been reported by Harold Harpster (2007), Stephanie Veldman, (2006) and Lawrence and Mark, (2006). Considering to day prices of yellow corn and soyabean meal $44 \%$,cost saving/MT of feed at the $20 \%$ level of DDGS inclusion is L.E.12(\$2.1)/ MT of feed (according to December, 2010).

\section{Ruminal parameters}

Data presented in Table (4) revealed that the ruminal $\mathrm{pH}$ value with different experimental groups appeared to gradually decrease with progress time after feeding. Moreover, significant $(\mathrm{P}<0.05)$ differences were found among group fed rations $A$ and both of those fed rations $B$ and $C$ at 3 and 6 hours. The rumen $\mathrm{pH}$ values tended to be significantly $(\mathrm{P}<0.05)$ higher for animals fed the tested rations containing DDGS than those fed control ration. Overall mean of ruminal $\mathrm{pH}$ values showed the highest value (6.84) was recorded for the group fed ration C (containing 20\% DDGS), followed by those fed ration B (containing 10\% DDGS) and the lowest value was recorded with groups fed control ration (ration $A$ ).

Also, the rumen $\mathrm{pH}$ value is one of the important factors affecting fermentation in the rumen. It varies in a regular manner depending on the nature of the ration and on the time that it is measured after feeding and reflects change of organic acid quantities in the digestia (Abdel-Kareem, 1990).

Ammonia- $\mathrm{N}$ concentration in rumen liquor showed the lowest level at before feeding and increased to the highest level at $6 \mathrm{hrs}$ after feeding. Adding $20 \%$ DDGS in ration $(C)$ tented to significantly $(P<0.05)$ induce higher $\mathrm{NH}_{3}-\mathrm{N}$ concentration, while this increase with ration $\mathrm{B}$ was not significant (Table, 4). The overall means of ruminal $\mathrm{NH}_{3}-\mathrm{N}$ concentration 
recorded $26.16,27.48$ and $28.12 \mathrm{mg} / 100 \mathrm{ml}$ for animals fed rations $\mathrm{A}, \mathrm{B}$, and $C$, respectively, showing higher values with animals fed rations containing DDGS (rations $B$ and $C$ ).

Table (4): Ruminal parameters of Friesian calves fed experimental rations

\begin{tabular}{|l|c|c|c|c|}
\hline \multirow{2}{*}{ Items } & Time of sampling & \multicolumn{3}{|c|}{ Experimental rations } \\
\cline { 3 - 5 } & After feeding & $\mathbf{A}$ & $\mathbf{B}$ & $\mathbf{C}$ \\
\hline & $0 \mathrm{hr}$ & $7.25^{\mathrm{a}}$ & $7.58^{\mathrm{a}}$ & $7.82^{\mathrm{a}}$ \\
\hline $\mathrm{pH}$ & $3 \mathrm{hr}$ & $6.14^{\mathrm{a}}$ & $6.72^{\mathrm{b}}$ & $6.91^{\mathrm{b}}$ \\
\hline & $6 \mathrm{hr}$ & $5.12^{\mathrm{a}}$ & $5.60^{\mathrm{b}}$ & $5.80^{\mathrm{b}}$ \\
\hline Overall average for $\mathrm{pH}$ & & 6.17 & 6.63 & 6.84 \\
\hline $\mathrm{NH}_{3}-\mathrm{N}(\mathrm{mg} . / 100 \mathrm{ml})$ & $0 \mathrm{hr}$ & $24.16^{\mathrm{a}}$ & $26.42^{\mathrm{b}}$ & $26.51^{\mathrm{b}}$ \\
\hline & $3 \mathrm{hr}$ & $26.15^{\mathrm{a}}$ & $27.19^{\mathrm{ab}}$ & $28.02^{\mathrm{b}}$ \\
\hline & $6 \mathrm{hr}$ & $28.18^{\mathrm{a}}$ & $28.82^{\mathrm{a}}$ & $29.84^{\mathrm{b}}$ \\
\hline Overall average for $\mathrm{NH}_{3}-\mathrm{N}$ & & 26.16 & 27.48 & 28.12 \\
\hline Total VFA's (meq. $100 \mathrm{ml})$ & $0 \mathrm{hr}$ & $10.18^{\mathrm{b}}$ & $11.73^{\mathrm{a}}$ & $11.25^{\mathrm{a}}$ \\
\hline & $3 \mathrm{hr}$ & $9.34^{\mathrm{b}}$ & $10.92^{\mathrm{a}}$ & $10.84^{\mathrm{a}}$ \\
\hline & $6 \mathrm{hr}$ & $9.87^{\mathrm{b}}$ & $11.20^{\mathrm{a}}$ & $10.86^{\mathrm{a}}$ \\
\hline Overall average for VFA's & & 9.79 & 11.28 & 11.02 \\
\hline
\end{tabular}

$a$ and $b$ : Means in the same row with different superscripts are differ $(P<0.05)$.

The concentrate of ruminal total VFA's had lower values at $3 \mathrm{hrs}$ after feeding, then it increased at 6 hrs post feeding, showing significantly $(\mathrm{P}<0.05)$ higher values with tested rations (containing DDGS) at different periods, as shown in Table (4). The same trend was observed with overall averages which increase with rations containing the DDGS. In general, the higher TVFA's concentration might be attributed to several factors such as DM digestibility, rate of absorption, rumen $\mathrm{pH}$, rate of passage of digestia and microbial population in the rumen and their activities (Allam et al., 1984). Also, such fluctuations in $\mathrm{pH}$ values and other ruminal parameters including $\mathrm{NH}_{3}-\mathrm{N}$ and total VFA's concentration could be attributed to different variable factors, mainly ration composition, feeding type and its level, roughage to concentrate ratio and time sampling.

\section{Blood parameters}

Some serum blood parameters are illustrated in Table (5). The blood total protein recorded were $6.42,6.85$ and $6.76 \mathrm{gm} / 100 \mathrm{ml}$ for animals fed rations $\mathrm{A}, \mathrm{B}$ and $\mathrm{C}$, respectively,with no significant differences. However, the animals fed rations containing either $10 \%$ or $20 \%$ DDGS tended to have higher blood total protein concentration. The same trend was observed with albumin and globulin concentration, with no significant differences too. Albumin/globulin ratio as the reflection of both albumin and globulin concentrations, indicating higher ratio with animals fed ration $\mathrm{B}$. On the contrary, blood creatinin value appeared to have the highest concentration with animals fed ration $\mathrm{A}$ followed by those fed rations $\mathrm{B}$ and C (containing 10\% and 20\% DDGS, respectively). However, these differences were not significant (Table 5). 
Results concerning albumin, globulin and $A / G$ ratio were within the normal ranges as reported by Fouda (2005).

Table (5): Serum blood parameters of Friesian calves fed different experimental rations

\begin{tabular}{|l|c|c|c|c|}
\hline \multirow{2}{*}{ Items } & \multicolumn{2}{|c|}{ Experimental rations } & Standard error ( \pm SE) \\
\cline { 2 - 5 } & A & B & C & \\
\hline Total protein, $(\mathrm{gm} / 100 \mathrm{ml})$ & $6.42^{\mathrm{a}}$ & $6.85^{\mathrm{a}}$ & $6.76^{\mathrm{a}}$ & 0.26 \\
\hline Albumin, (gm/100ml) & $3.24^{\mathrm{a}}$ & $3.65^{\mathrm{a}}$ & $3.50^{\mathrm{a}}$ & 0.10 \\
\hline Globulin, (gm/100ml) & $3.18^{\mathrm{a}}$ & $3.20^{\mathrm{a}}$ & $3.26^{\mathrm{a}}$ & 0.08 \\
\hline Albumin/globulin ratio & 1.02 & 1.14 & 1.07 & - \\
\hline Creatinin, (mg/dl) & $1.25^{\mathrm{a}}$ & $1.12^{\mathrm{a}}$ & $1.15^{\mathrm{a}}$ & 0.08 \\
\hline
\end{tabular}

$a$ and $b$ : Means in the same row with different superscripts are differ $(P<0.05)$.

\section{Conclusion}

The present results showed that DDGS could be concluded that the incorporation DDGS at the rate up to $20 \%$ in the concentrate feed mixture of the rations for fattening Friesian calves significantly $(P<0.05)$ increased digestibility coefficients of most of nutrients and the feeding values expressed as TDN and DCP,in addition to increase daily gain, improved feed conversion efficiency respectively. At the same time, animals fed rations containing DDGS at the rate up to $20 \%$ tended to give more weight with lower feed cost and higher feed and economical efficiencies. Further work is needed to explore the possibility of including DDGS at rates higher than $20 \%$ in fattening rations for beef animals. Also, the proper level of DDGS to be used in dairy cattle rations need to be explored.

\section{Acknowledgement}

Authors are wish to express their sincere appreciation and deepest gratitude to Dr. H. Soliman, Professor of Animal Nutrition, Faculty of Agriculture Ain Shams University for his support and helps throughout this work as well as his useful guidance and valuable criticisms.

\section{REFERENCES}

A.O.A.C. (1995). Association of Official Agriculture Chemists, Official Methods of Analysis, $15^{\text {th }}$ Ed., Washington, D.C.

Abdel-Kareem, F.A. (1990). Improvement the utilization of roughage by goats. Ph.D. Thesis, Fac. Agric., Cairo Univ.

Allam, S.M.; A.K. Abu-Raya; E.A. Gihad and Y.M. El-Bedawy (1984). Nutritional studies by sheep and goats fed $\mathrm{NaOH}$ treated straw. $1^{\text {st }}$ Egyptian British Conf. on Anim. and Poultry Production, Zagazig Univ., 11-13 Sep., p. 53.

Conway, E.E. (1957). Modification Analysis and Volumetric Error. Rev. Ed. Lockwood., London.

Cornell, A.G.; Badawill, C.J. and David, M.M. (1949). Determination of serum proteins by means of the buiret reaction. J. Biochem., 177: 551 . 
DeHaan, K.; Klopfenstein, T.J.; Stock, R.; Abrams, S. and Britton, R.A. (1982). Wet distiller by-products for growing ruminants. Beef-cattle report, Agricultural Exp. Stat. Inst. Agriculture and Natural Resources, Nebraska-Lincolon Univ., USA.

Doumas, B.; Wabson, W. and Biggs, H. (1971). Albumin standard and measurement of serum with bromocresol green (Lin-Chem. Acta., 31: 287).

Duncan, D.B. (1955). Multiple range and Multiple F-test. Biometrics, 11: 1-42.

Etman, K.E.I.; Zeid, A.M.M. and El-Monayer, T.I. (2001). Effect of feeding two carbohydrate source in ration of buffalo calves on feed utilization and growth performance. Egyptian J. Nutr. and feed, Vol. (4), special issue.

Fouda, S.M.I. (2005). Nutritional evaluation of silage of some agricultural byproducts. Ph.D. Thesis, Fac. Agric., Al-Azhar Univ., Cairo, Egypt.

Ham, G.A.; Stock, R.A; Klopfenstein, T.J.; Larson, E.M.; Shain, D.H. and Huffman, R.P. (1994). Wet corn distiller by-products compared with dried corn distiller grains with solubles as sources of protein and energy for ruminants. Journal of Animals Sci., 72(12): 3246-3257.

Harold Harpster (2007) Feed potential of biofuel co-products corn distiller grains. Penn state Renewable In-service Training Program, Dept. of Dairy and Animal Science, Nov. 15, Penn State, USA.

Kleinschmit, D.H.; Schingoethe, D.J.; Kalscheur, K.F and Hippen, A.R. (2006). Evaluation of various sources of corn dried distiller grains plus soluble for lactating dairy cattle. Journal of Dairy Sci., 89 (12): 4784-4794.

Lawrence, J.D. and Darell Mark (2006). Corn co-products in beef cow rations. Report of lowa State Univ. and Nebraska Univ for Beef Cattle. http://beef.Unl.edu/reports.sktn.

Leupp, J.L.; G.P. Lardy; K.K. Karges; M.L. Gibson and T.S. Caton (2009). Effect of increasing level of corn distiller dried grains with solubles on intake, digestion and ruminal fermentation in steers fed seventy percent concentrate diets. J. Anim. Sci., 87: 2906.

May, M.L.; M.J. Quinn; B.E. Depenbusch; C.D. Reinhardt; .L. Gibson, K.K. Karges; N.A. Cole and J.S. Drouillard (2009). Dried distiller grain with soluble with reduced corn silage level in beef finishing diets. J. Anim. Sci., vol. (10): 2527.

NRC (1989). Nutrient Requirements of Domestic Animals. Nutrient Requirements of cattle. National Research Council, National Academy of Science. Washington, D.C., USA.

Reed, J.J.; Lardy, G.P.; Bauer, M.L.; Gibson, M. and Caton, J.S. (2006). Effect of season and inclusion of corn distiller dried grains with soluble in creeps feed on intake, microbial protein synthesis and efficiency, ruminal fermentation, digestion and performance of nursing calves grazing native range in Southwestern, North Dekota. J. Anim. Sci., vol. 84 (8).

SAS, (1996). Statistical analysis system/ User's Guide Static's Ver, 6-06 $4^{\text {th }}$ ED. SAS Institute Inc., Cary, NC.

Stephanie Veldman (2006). Ethanol-Powered Cows, Magazine Articles, Penton, $1^{\text {st }}$ September, http://beef Magazine.com. 
Trankle, A. (2003). Evaluation of wet and dry distiller grains with soluble for finishing steers. Reports to lowa corn promotion board, Nov., lowa Univ., USA.

Warner, A.C.I. (1964). Production of volatile fatty acids in the rumen methods of measurements. Nutrition Abstr. And Rev., 34: 339.

Widmers, M.R.; L.M.MC Ginnis; D.M. Wulf and H.H. Stein (2008). Effect of feeding distiller dried grains with soluble, high-protein distiller dried grains and corn germ to growing-finishing pigs on pig performance, carcass quality and the palatability of pork. J. Anim. Sci., 88(8): 18191831.

Young, D.S. (1990). Effect of drug on clinical laboratory tests. $3^{\text {rd }}$ Ed-AACC press, Washington, D.C., USA.

$$
\begin{aligned}
& \text { الإستفادة من مصادر غذائية جديدة في تغذية المجترات: }
\end{aligned}
$$

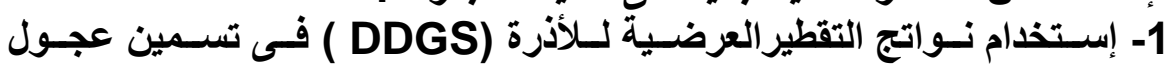

$$
\begin{aligned}
& \text { الفريزيان } \\
& \text { كامل عتمان إبراهيم عتمان، عبد المنعم محمد مصطقى زيد و طارق إبراهيم المنيم الهنير } \\
& \text { معهل بحوث الإنتاج الحيو اني ـ مركز البحوث الزئماعية ــ الجيزة - ج.م.ع. }
\end{aligned}
$$

